\title{
Crystal structure of diindium digermanate, $\operatorname{In}_{2}\left(\mathrm{Ge}_{2} \mathrm{O}_{7}\right)$
}

\author{
A. Pfeifer. R. Wartchow* and M. Binnewies \\ Universität Hannover. Institut für Anorganische Chemie, Callinstr. 9. D-30I67 Hannover. Germany
}

Received October 19. 2000. CSD-No. 409548

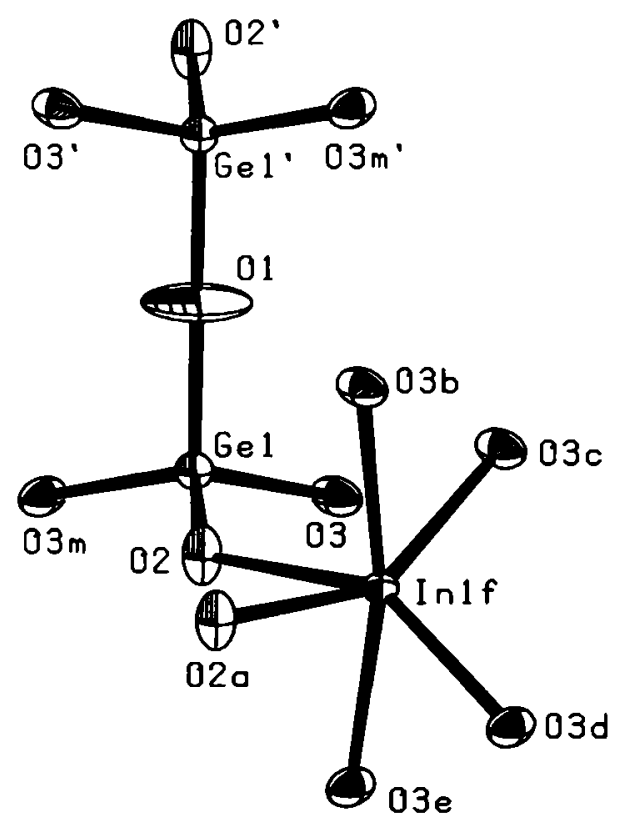

\begin{abstract}
$\mathrm{Ge}_{2} \mathrm{In}_{2} \mathrm{O}_{7}$, monoclinic, $C 12 / m \mathrm{l}$ (No. 12), $a=6.647(2) \AA$, $b=8.773(2) \AA, c=4.918(1) \AA, \beta=102.50(3)^{\circ}, V=280.0 \AA^{3}$, $Z=2, R_{\mathrm{gt}}(F)=0.016, w R_{\text {ref }}\left(F^{2}\right)=0.039, T=300 \mathrm{~K}$.
\end{abstract}

\section{Source of material}

Single crystals of indium digermanate were grown by chemical vapor transport of $\operatorname{In}_{2} \mathrm{O}_{3}$ and $\mathrm{GeO}_{2}$ in a closed quartz ampoule. Chlorine $(0.5 \mathrm{mmol})$ was used as transport agent and a mixture of $\mathrm{In}_{2} \mathrm{O}_{3}(1.5 \mathrm{mmol})$ and $\mathrm{GeO}_{2}(3 \mathrm{mmol})$ as source materials. After one day of heating in a temperature gradient $(1273 \mathrm{~K} \rightarrow 1373 \mathrm{~K})$, the transport was conducted for eight days in the inverse gradient. In a homogenous transport indium digermanate was deposited in the crystallization zone with a transport rate of $2 \mathrm{mg} / \mathrm{h}$.

\begin{abstract}
Discussion
The (average) crystal structure of $\operatorname{In}_{2} \mathrm{Ge}_{2} \mathrm{O}_{7}$ is isotypic to that of $\mathrm{In}_{2} \mathrm{Si}_{2} \mathrm{O}_{7}$ [1]. The $\mathrm{Ge}-\mathrm{O}$ distances range from $170 \mathrm{pm}$ to $175 \mathrm{pm}$ and the In-O distances from $211 \mathrm{pm}$ to $222 \mathrm{pm}$. The two longest half axes of the anisotropic displacement ellipsoid of the bridging oxygen atom $\mathrm{Ol}$ are larger than those in $\ln _{2} \mathrm{Si}_{2} \mathrm{O}_{7}$ by a factor of two. Therefore a structure model with a splitted $\mathrm{Ol}$ atom (two $\mathrm{O}_{1 / 4}$ atoms in, one $\mathrm{O}_{1 / 4}$ above and one $\mathrm{O}_{1 / 4}$ below the mirror plane) was refined, too. This refinement was stable and converged to $R$ values as low as in the average structure. As a result one obtains for the distance $\mathrm{Ge}-\mathrm{O} 1$ 172.4(4) pm and for the angle $\mathrm{Ge}-\mathrm{O} 1-\mathrm{Ge}^{\prime} 162(1)^{\circ}$. An analogous calculation for $\mathrm{In}_{2} \mathrm{Si}_{2} \mathrm{O}_{7}$ yields for the distance Si-O1 161.6(3) pm and for the angle $\mathrm{Si}-\mathrm{Ol}-\mathrm{Si}^{\prime} \mathrm{169}(2)^{\circ}$. A recent discussion of a linear $\mathrm{Si}-\mathrm{O}-\mathrm{Si}$ bond is given in [2].
\end{abstract}

Table 1. Data collection and handling.

\begin{tabular}{ll}
\hline Crystal: & colourless prism, \\
& size $0.11 \times 0.204 \times 0.39 \mathrm{~mm}$ \\
Wavelength: & $\begin{array}{l}\text { Mo } K_{\alpha} \text { radiation }(0.71073 \AA) \\
187.49 \mathrm{~cm}^{-1}\end{array}$ \\
$\mu:$ & Stoe IPDS, 240 exposures, $\Delta \phi=1.5^{\circ}$ \\
Diffractometer, scan mode: & $60.98^{\circ}$ \\
$2 \theta_{\text {max }}:$ & 2671,426 \\
$N(h k l)_{\text {measured, }} N(h k l)_{\text {unique: }}:$ & $I_{\text {obs }}>2 \sigma\left(I_{\text {obs }}\right), 418$ \\
Criterion for $I_{\text {obs }}, N(h k l)_{\text {gl }}:$ & 32 \\
$N(\text { param })_{\text {refined: }}$ & SHELXL-93 [3], CIF2SX [4], PLATON [5] \\
Programs: &
\end{tabular}

Table 2. Atomic coordinates and displacement parameters (in $\AA^{2}$ ).

\begin{tabular}{|c|c|c|c|c|c|c|c|c|c|c|}
\hline Atom & Site & $x$ & $y$ & $z$ & $U_{11}$ & $U_{22}$ & $U_{33}$ & $U_{12}$ & $U_{13}$ & $U_{23}$ \\
\hline $\ln (1)$ & $4 g$ & 0 & $0.30714(3)$ & 0 & $0.0034(2)$ & $0.0049(2)$ & $0.0048(2)$ & 0 & $0.00045(9)$ & 0 \\
\hline $\mathrm{Ge}(1)$ & $4 i$ & $0.23254(5)$ & 0 & $0.40752(7)$ & $0.0047(2)$ & $0.0054(3)$ & $0.0033(2)$ & 0 & $-0.0001(1)$ & 0 \\
\hline$O(1)$ & $2 c$ & 0 & 0 & $1 / 2$ & $0.012(2)$ & $0.047(4)$ & $0.056(4)$ & 0 & $0.023(2)$ & 0 \\
\hline$O(2)$ & $4 i$ & $0.4084(4)$ & 0 & $0.7282(5)$ & $0.012(1)$ & $0.006(2)$ & $0.005(1)$ & 0 & $-0.0017(9)$ & 0 \\
\hline$O(3)$ & $8 j$ & $0.2391(3)$ & $0.1658(3)$ & $0.2121(4)$ & $0.0062(7)$ & $0.009(1)$ & $0.0094(8)$ & $0.0024(6)$ & $0.0026(6)$ & $0.0045(7)$ \\
\hline
\end{tabular}

\footnotetext{
* Correspondence author (e-mail: wartchow@aca.uni-hannover.de)
} 
Acknowledgment. Computing facilities of RRZN (Hannover) were used.

\section{References}

1. Patzke. G. R.: Wartchow, R.; Binnewies, M.: Refinement of the crystal structure of diindium disilicate, $\operatorname{In}_{2} \mathrm{Si}_{2} \mathrm{O}_{7}$. Z. Kristallogr. NCS 215 (2000) 15-16 and the literature cited therein.

2. Haile, S. M.: Wuensch, B. J.: X-ray diffraction study of $\mathrm{K}_{3} \mathrm{NdSi}_{7} \mathrm{O}_{17}$ : a new framework silicate with a linear $\mathrm{Si}-\mathrm{O}-\mathrm{Si}$ bond. Acta Crystallogr. B56 (2000) 773-779
3. Sheldrick. G. M.: SHELXL-93, a program for refining crystal structures. University of Göttingen. Germany 1993.

4. Farrugia, L. J.: CIF2SX, a program to extract a SHELX-ins-file from a CIF. University of Glasgow. UK 1997.

5. Spek A. L.: PLATON. an integrated tool for the analysis of the results of a single crystal structure determination. Acta. Crystallogr. A46 (1990) C-34. 